\title{
Strategic Emerging Industries in China: Literature Review and Research Prospect
}

\author{
Dongbei $\mathrm{Xu}^{1,2}$, Jianmin Wang1 \\ ${ }^{1}$ School of Government, Beijing Normal University, Beijing, China \\ ${ }^{2}$ School of Business Administration, Tonghua Normal University, Tonghua, China \\ Email: xdb8056@126.com
}

Received 25 June 2015; accepted 27 July 2015; published 30 July 2015

Copyright (C) 2015 by authors and Scientific Research Publishing Inc.

This work is licensed under the Creative Commons Attribution International License (CC BY). http://creativecommons.org/licenses/by/4.0/

c) (i) Open Access

\begin{abstract}
Based on the research articles about the strategic emerging industries in China of Chinese Social Sciences Citation Index (CSSCI) on http://www.cnki.net/ from 2010 to 2014, we analyze the research literature from quantitative and qualitative perspective and prospect the future research directions of the strategic emerging industries in China. The research data shows that the studies on strategic emerging industries in China have developed rapidly these years, the high-level research results are increasingly abundant, but some problems should be further studied. And we believe that the researchers should focus on the empirical studies based on the development of the practices, and make efforts to construct a whole systematic research framework and pay more attention to the studies on strategic human resources.
\end{abstract}

\section{Keywords}

Chinese Social Sciences Citation Index (CSSCI), China National Knowledge Infrastructure (CNKI), Strategic Emerging Industries, Literature Review, Strategic Human Resource

\section{Introduction}

China's former premier Wen Jiabao first proposed the concept of strategic emerging industries in September 2009. Strategic emerging industries in China are those industries which are established based on major breakthroughs attained in cutting-edge science and technology; represent the new direction of the development of the future science \& technology and industry; reflect the trend of the development of knowledge economy, low-carbon economy and circular economy in the world today; have great potentials but are still in early growth; and play a significant leading role in economy and society. Nowadays, Strategic emerging industries in China include those related to energy-saving and environmental protection, new generation of information technology, 
biology, high-end equipment manufacturing, new energy, new materials and new-energy automobiles. Strategic emerging industries are important forces to lead the future social and economic development. Developing strategic emerging industries have become a significant strategy of major countries in the world to seize the high ground of a new round of economic and technological development.

In a speech delivered at the Asia-Pacific Economic Cooperation (APEC) CEO Summit on November 9, 2014, Chinese president Xi Jinping said that a "new normal" of China's economy had emerged with several notable features which included gear shifting from the previous high speed to a medium-to-high speed growth, improvement and upgrading of the economic structure, and innovation as a stronger economy driver than input and investment. The "new normal" of China's economy gives new opportunities for the development of strategic emerging industries. Accelerating the development of strategic emerging industries is essential for speeding up the transformation of China's economic development pattern, enhancing the country's international competitiveness and building an innovation-oriented country.

As the key for promoting economic transformation, optimizing the industrial structure and seizing the commanding heights in international competition, and strategic emerging industry has been one of the hotspots of academic research. So we review and analyze the research articles about strategic emerging industries to prospect the future research directions.

\section{Literature Review}

We reviewed and analyzed the research literature about strategic emerging industries in China from quantitative and qualitative perspective.

\subsection{Quantitative Analysis}

In the past five years, the research on strategic emerging industries in China has developed rapidly (see Figure 1). Taking "strategic emerging industries" as an article keyword, we searched 758 articles through the Chinese Social Sciences Citation Index (CSSCI) on the website of http://www.cnki.net/. Reviewing the research articles by the method of bibliometrics analysis, we found that the studies show some characteristics as follows:

- The research contents of strategic emerging industries in China are multi-disciplinary, but mainly focus on business economics, macroeconomic management and sustainable development, economic structural reform, finance \& accounting, which account for $68.73 \%, 20.58 \%, 16.89 \%$ and $10.42 \%$ of the total quantity, respectively; are multi-level, but concentrate mainly on basic research (social sciences) and policy research (social sciences), which account for $58.58 \%$ and $37.60 \%$ of the total quantity, respectively (see Table 1 , Table 2).

- The research institutions of strategic emerging industries in China concentrate mainly on colleges, universities and research institutes, such as Dongbei University of Finance and Economics, Nanjing University, Institute of Industrial Economics of Chinese Academy of Social Sciences and so on (see Table 3).

- The journals of research on strategic emerging industries in China are mainly academic journals of economics and management, such as Science \& Technology Progress and Policy, Forum on Science and Technology in China, Scientific Management Research, Science of Science and Management of S. \& T., Economic Review and so on (see Table 4).

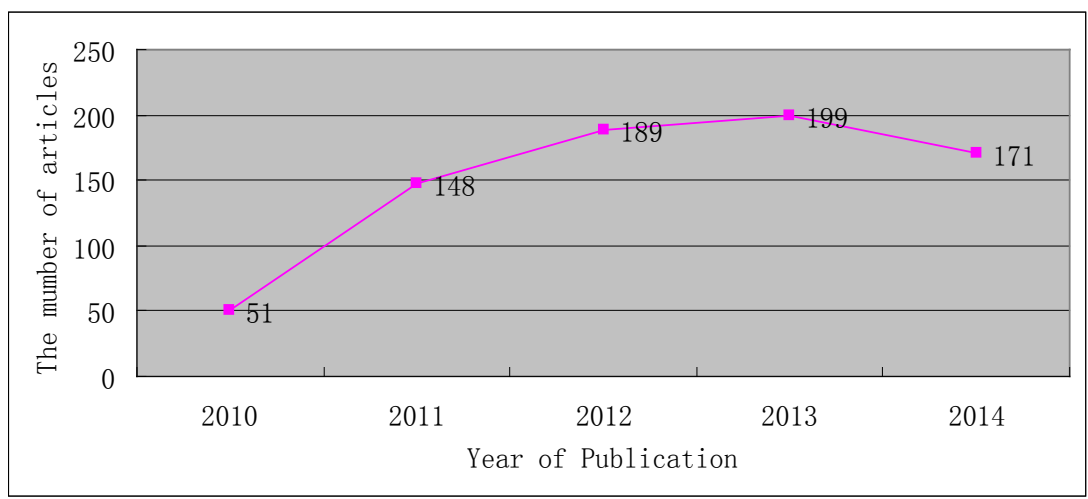

Figure 1. The number of articles about strategic emerging industry in China through CSSCI. 
Table 1. Main subjects researching on strategic new emerging industry in China (Top 20).

\begin{tabular}{clcc}
\hline No. & \multicolumn{1}{c}{ Subjects } & The number of articles & Proportion (\%) \\
\hline 1 & Business Economics & 521 & 68.73 \\
2 & Macroeconomic Management and Sustainable Development & 156 & 20.58 \\
3 & Economic Structural Reform & 128 & 16.89 \\
4 & Finance \& Accounting & 79 & 10.42 \\
5 & Industrial Economics & 53 & 6.99 \\
6 & Public Finance and Tax & 40 & 5.28 \\
7 & Investment & 29 & 3.83 \\
8 & Securities & 16 & 2.11 \\
9 & Market Research and Information & 15 & 1.98 \\
10 & Scientific Research Management & 13 & 1.72 \\
11 & Oceanography & 13 & 1.72 \\
12 & Mathematics & 11 & 1.45 \\
13 & Talent Studies and Labour Science & 10 & 1.31 \\
14 & Economic theory and History of Economic Thought & 10 & 1.31 \\
15 & Higher Education & 9 & 1.19 \\
16 & Organic Chemicals & 8 & 1.06 \\
17 & Power Engineering & 6 & 0.79 \\
18 & Information Economy and Postal Service Economy & 4 & 0.53 \\
19 & Automotive Industry & 4 & 0.53 \\
\hline
\end{tabular}

Table 2. Main research levels concerning strategic new emerging industry in China.

\begin{tabular}{clcc}
\hline No. & \multicolumn{1}{c}{ Research levels } & The number of articles & Proportion (\%) \\
\hline 1 & Basic Research (Social Sciences) & 444 & 58.58 \\
2 & Policy Research (Social Sciences) & 285 & 37.60 \\
3 & Industry Guidance (Social Sciences) & 16 & 2.11 \\
4 & Basic and Applied Basic Research (Natural Sciences) & 6 & 0.79 \\
5 & Higher Education & 5 & 0.66 \\
6 & Policy Research (Natural Sciences) & 2 & 0.26 \\
\hline
\end{tabular}

Table 3. Main academic institutions paying attention to strategic new emerging industry in China (Top 20).

\begin{tabular}{clcc}
\hline No. & \multicolumn{1}{c}{ Institutions } & The number of articles & Proportion (\%) \\
\hline 1 & Dongbei University of Finance and Economics & 27 & 3.56 \\
2 & Nanjing University & 21 & 2.77 \\
3 & Institute of Industrial Economics of Chinese Academy of Social Sciences & 20 & 2.64 \\
4 & Sichuan University & 19 & 2.51 \\
5 & Central South University & 17 & 2.24 \\
6 & Jilin University & 13 & 1.72 \\
7 & Xi'an Jiaotong University & 13 & 1.72 \\
8 & Changsha University of Science \& Technology & 13 & 1.72 \\
9 & Beijing University of Technology & 12 & 1.58 \\
10 & Hunan University & 12 & 1.58 \\
11 & Tsinghua University & 11 & 1.45 \\
12 & East China Normal University & 11 & 1.45 \\
13 & Donghua University & 10 & 1.32 \\
14 & Wuhan University & 10 & 1.32 \\
15 & Zhongnan University of Economics and Law & 10 & 1.32 \\
16 & Harbin University of Science and Technology & 9 & 1.19 \\
17 & Chinese Academy of Science and Technology for Development & 9 & 1.19 \\
18 & Southeast University & 9 & 1.19 \\
19 & Shanghai University of Finance and Economics & 9 & 1.19 \\
20 & Nankai University & 9 & 8 \\
\hline
\end{tabular}


Table 4. Core journals focusing in strategic new emerging industry in China (Top 20).

\begin{tabular}{|c|c|c|c|c|}
\hline No. & Journals & $\begin{array}{l}\text { The composite } \\
\text { impact factor }\end{array}$ & $\begin{array}{l}\text { The number } \\
\text { of articles }\end{array}$ & $\begin{array}{l}\text { Proportion } \\
\text { (\%) }\end{array}$ \\
\hline 1 & Science \& Technology Progress and Policy & 1.458 & 65 & 8.58 \\
\hline 2 & Forum on Science and Technology in China & 1.848 & 35 & 4.62 \\
\hline 3 & Scientific Management Research & 1.235 & 28 & 3.69 \\
\hline 4 & Science of Science and Management of S. \& T. & 2.075 & 21 & 2.77 \\
\hline 5 & Economic Review & 1.254 & 17 & 2.24 \\
\hline 6 & Reform of Economic System & 1.204 & 15 & 1.99 \\
\hline 7 & Modern Economic Research & 1.221 & 13 & 1.72 \\
\hline 8 & Macroeconomic Management & 0.575 & 12 & 1.58 \\
\hline 9 & Reform & 1.689 & 11 & 1.45 \\
\hline 10 & Economic Management Journal & 1.021 & 11 & 1.45 \\
\hline 11 & Research on Financial and Economic Issues & 1.817 & 11 & 1.45 \\
\hline 12 & Inquiry into Economic Issues & 1.449 & 11 & 1.45 \\
\hline 13 & Macroeconomics & 1.832 & 9 & 1.19 \\
\hline 14 & Fujian Tribune (The Humanities \& Social Sciences Monthly) & 0.647 & 7 & 0.92 \\
\hline 15 & Taxation Research & 0.963 & 7 & 0.92 \\
\hline 16 & Science and Technology Management Research & 0.822 & 7 & 0.92 \\
\hline 17 & China Industrial Economics & 4.875 & 7 & 0.92 \\
\hline 18 & Statistics \& Decision & 0.847 & 7 & 0.92 \\
\hline 19 & Seeker & & 6 & 0.79 \\
\hline 20 & China Soft Science & 3.414 & 6 & 0.79 \\
\hline
\end{tabular}

- Table 5 shows that the researchers of strategic emerging industries in China are more productive, the top three of whom are Xiong Yongqing, He Zhengchu, Xiao Xingzhi.

- Table 6 shows $45.38 \%$ supported by national grants, $54.62 \%$ supported by all kinds local grants. This reflects the related departments of both the central and local governments attach great importance to the studies on strategic emerging industries.

\subsection{Qualitative Analysis}

Theories for traditional industries cannot be simply transplanted to strategic emerging industries. Inquiry into strategic emerging industries should start from abstracting and refining its economic characteristics and then conceptualizing and constructing an analytical framework which identifies key technological, economic and institutional factors that affect the development of strategic emerging industries; explores the adoption and dynamic fitness between those factors; and figures out at which level and point (national, industrial or firm level) that the influence and fitness happen [1]. We select 76 articles according to the composite impact factor of journals (>2) after two rounds of reading the articles (see Table 7). On the basis of careful analyses of research contents about strategic emerging industries, we conclude that the studies mainly focus on four aspects as follows.

\subsubsection{Research on Industries Supporting Factors}

To support the development of strategic emerging industries, a lot of measures must be taken, including government innovation subsidies or funds, industry policies, financial policies and so on.

\section{1) Government Innovation Subsidies or funds}

Wang, Y. and Liu, Z.B. (2013) [2] used a sector-specific model to analyze impacts of different subsidy policies on traditional and emerging industries respectively. They found that production subsidies might lead to short-term and unsustainable development of emerging industries at the cost of negative impact on traditional industries and technology progress of aggregate economy in the long run, when bilateral knowledge spillover existed between different industries. On the other hand, effect of R \& D subsidies depended on characteristics of knowledge spillover. When R \& D activities can only promote technology progress within the industry, industry-specific R \& D subsidies would realize expanding of subsidized industry and shrinking of the other industry. 
Table 5. Main researchers devoted to strategic new emerging industry in China (Top 20).

\begin{tabular}{cccccc}
\hline No. & Authors & The number of articles & No. & Authors & The number of articles \\
\hline 1 & Xiong Yongqing & 13 & 11 & Yang Yiwen & 5 \\
2 & He Zhengchu & 11 & 12 & Wang Xinxin & 5 \\
3 & Xiao Xingzhi & 11 & 13 & Liu Zhiyang & 5 \\
4 & Gu Haifeng & 9 & 14 & Liu Tie & 5 \\
5 & Cheng Guisun & 8 & 15 & Wang Jiuyun & 5 \\
6 & Lv Tie & 7 & 16 & Wang Hongqi & 5 \\
7 & Ma Junwei & 6 & 17 & Wu Shaobo & 5 \\
9 & Huang Lucheng & 6 & 18 & Gu Xin & 5 \\
\hline
\end{tabular}

Table 6. Grants supporting the Study on the strategic new emerging industry in China (Top 20).

\begin{tabular}{|c|c|c|c|}
\hline No. & Grants & The number of articles & Proportion (\%) \\
\hline 1 & National Social Science Foundation of China & 188 & 24.80 \\
\hline 2 & National Natural Science Foundation of China & 103 & 13.59 \\
\hline 3 & National Soft Science Research Program & 32 & 4.22 \\
\hline 4 & China Postdoctoral Science Foundation & 21 & 2.77 \\
\hline 5 & Philosophy and Social Science Foundation of Hunan Province & 16 & 2.11 \\
\hline 6 & Soft Science Fund of Hunan Province & 15 & 1.98 \\
\hline 7 & Soft Science Fund of Sichuan Province & 10 & 1.32 \\
\hline 8 & $\begin{array}{l}\text { Philosophy and Social Science Foundation of the Department of } \\
\text { Education of Jiangsu Province }\end{array}$ & 10 & 1.32 \\
\hline 9 & $\begin{array}{l}\text { Social Development Fund of Science and Technology Committee } \\
\text { of Jiangsu Province }\end{array}$ & 8 & 1.06 \\
\hline 10 & Scientific Research Funds of the Education Commission of Hunan Province & 6 & 0.79 \\
\hline 11 & Natural Science Foundation of Hunan Province & 5 & 0.66 \\
\hline 12 & Soft Science Fund of Henan Province & 5 & 0.66 \\
\hline 13 & Soft Science Fund of Shanghai & 5 & 0.66 \\
\hline 14 & Soft Science Fund of Shanxi Province & 5 & 0.66 \\
\hline 15 & Science and Technology Development Plan Fund of Jilin Province & 5 & 0.66 \\
\hline 16 & Soft Science Fund of Hubei Province & 4 & 0.53 \\
\hline 17 & Soft Science Fund of Hebei Province & 4 & 0.53 \\
\hline 18 & Soft Science Fund of Fujian Province & 4 & 0.53 \\
\hline 19 & Soft Science Fund of Anhui Province & 4 & 0.53 \\
\hline 20 & Science and Technology Plan Projects of Beijing & 4 & 0.53 \\
\hline
\end{tabular}


Table 7. The selected journals and articles.

\begin{tabular}{|c|c|c|c|}
\hline No. & Journals & The composite impact factor & The selected number of articles \\
\hline 1 & Economic Research Journal & 9.555 & 1 \\
\hline 2 & Accounting Research & 6.902 & 1 \\
\hline 3 & China Industrial Economics & 4.875 & 7 \\
\hline 4 & China Soft Science & 3.414 & 6 \\
\hline 5 & The Journal of Quantitative \& Technical Economics & 3.374 & 1 \\
\hline 6 & Management World & 3.015 & 2 \\
\hline 7 & Issues in Agricultural Economy & 2.924 & 3 \\
\hline 8 & Studies in Science of Science & 2.769 & 8 \\
\hline 9 & Economic Geography & 2.762 & 1 \\
\hline 10 & Economic Theory and Business Management & 2.623 & 3 \\
\hline 11 & Finance \& Trade Economics & 2.622 & 2 \\
\hline 12 & Science Research Management & 2.582 & 2 \\
\hline 13 & Economist & 2.548 & 2 \\
\hline 14 & Modern Economic Science & 2.377 & 1 \\
\hline 15 & Journal of Finance and Economics & 2.217 & 1 \\
\hline 16 & Industrial Economics Research & 2.159 & 4 \\
\hline 17 & Journal of Zhongnan University of Economics and Law & 2.129 & 1 \\
\hline 18 & Comparative Economic \& Social Systems & 2.119 & 3 \\
\hline 19 & Securities Market Herald & 2.095 & 5 \\
\hline 20 & Science of Science and Management of S. \& T. & 2.075 & 22 \\
\hline \multicolumn{3}{|c|}{ Total } & 76 \\
\hline
\end{tabular}

But if R \& D in one industry has strong knowledge spillover in both industries, R \& D subsidies toward this industry will realize balanced growth of overall economy. Therefore, government should dynamically adjust R \& D subsidy scheme according to characteristics of alternating between emerging and traditional industries in different stages of industrial upgrading.

In order to analyze the R \& D incentive of enterprises, Xiao, X.Z. and Jiang, X.J. (2013) [3] divided the enterprises in the strategic emerging industries into traditional enterprises in transition and newborn enterprises. They undertook an econometric analysis of the effects of enter timing and firm size on R \& D expenditure by using the data of the listed companies of 103 strategic emerging enterprises from 2006 through 2011. They used Bootstrap test to examine whether there were statistically significant differences between regression coefficients of traditional enterprises in transition and newborn enterprises. Studies had shown that the newborn enterprises had greater R \& D incentives to innovate compared to traditional enterprises in transition which entered the strategic emerging industries at the same time point. By distinguishing R \& D incentives between different enterprises, government can implement innovation support policy more effectively.

The development of strategic emerging industries has been supported widely by all levels of governments, the subsidy policies can be reflected in this process. Han, C. (2014) [4] analyzed the strategic emerging industries with the data such as government subsidies, investment in R \& D from annual report. His research results showed actions of local governments were diversity; local government was apt to support the weak; local governments encouraged innovation and employment, which was part of performance appraisal from central government, which was influenced by economic status among regions; local government subsidy had strong prefe- 
rence for ownership types, while the probability, the number and the subsidy rate of the central state-owned enterprises were significantly lower than other types. Wu, Q. and Liu, B. (2014) [5] studied different influencing mechanism of different distribution modes of government R \& D subsidy on the innovation of strategic emerging industries. The analysis of dynamic game model stated, because the set-quota subsidy did not influence the product quality decision of the leading firm in the strategic emerging industries, it was not as effective as the ratio subsidy in improving the original innovation. Using the Sys-GMM method to estimate the dynamic panel data of Chinese listed companies in the strategic emerging industries from 2009 to 2013, they found that the set-quota R \& D subsidy accepted by Chinese listed companies in the strategic emerging industries did not affect the outcome of innovation which was measured by technological progress significantly, and the technology progress in the previous one period and current R \& D input of these listed companies improved the current innovation outcome positively and significantly. Finally, they suggested that the Chinese governments in the different levels need to change the popular mode of set-quota subsidy use the mode of ratio subsidy instead of the mode of set-quota subsidy and it can increase the innovation outcome of the strategic emerging industries.

As the main means to support the development of strategic emerging industries, Chinese government has had huge subsidies on these industries. How does the performance of government innovation subsidies? Lu, G.Q., Wang, Z. and Zhang C.Y. (2014) [6] conducted a systematic study on this issue. Firstly, creatively choosing these listed companies of strategic emerging industries as representative research sample, they manually collected and sorted the system data of innovation input and output over the period 2010-2012 from these firms' prospectus, regular reports, daily information disclosure information as well as company's web site and so on. Secondly, building a translog CDM model which included spillover effect, they estimated innovation subsidies on the output performance of Chinese strategic emerging industries' firms since 2010 by Iterative Three-Stage Least Squares (IT3SLS) method. Thirdly, using Partial Least Squares (PLS) method, they analyzed the main factors affecting performance of subsidizing innovation. Results showed that, (1) both R \& D spillovers and subsidizing innovation positively affected firms performance; (2) R \& D spillovers output elasticity was much higher than the output elasticity of subsidizing innovation which was small for a single enterprise; (3) corporate governance mechanisms and financials were significantly related to the performance of subsidizing innovation, the PLS method regression coefficient in descending order: asset-liability ratio, independent directors ratio, integrated lever coefficient, fixed assets ratio, controlling shareholder stake. Wang, Q.M., Han, Q.X. and Yang, C. (2014) [7] analyzed the conditions and influencing factors of the effectiveness of government subsidies in strategic emerging industries by constructing a dynamic game model between government subsidies and corporate behavior. Meanwhile, they made an empirical analysis to verify the influencing factors of the effectiveness of government subsidies based on the panel data of 80 listed companies belonging to seven categories of strategic emerging industries from 2002 to 2011. It arrived at the conclusion that with the inducement from government subsidies, the entry of potential enterprises into strategic emerging industries was rational behavior, but a majority of potential enterprises would invest the acquired funds into other high profit ways which were unrelated to the development of these industries after their entry. As a whole, government subsidies played an ineffective role in the promotion of R \& D input in strategic emerging industries, mainly owing to the difficulty in government control of corporate behavior as well as the absence of government punishment. But the sub-industry regression analysis results showed that government subsidies were effective in new energy industry and new energy automotive industry. The former can be explained by lower costs of government checks and the important role of government punishment; the latter can be mainly explained by the advantage of market exploitation owing to big corporate scale as well as effective R \& D owing to long business history.

Xiao, X.Z. and Wang, Y.P. (2014) [8] established a model about how an enterprise made the decision between its social capital and R \& D investment, and systematically analyzed the internal mechanism how an enterprise's investment decision was influenced by not only the external environment, such as the capability of government intervention, the distribution of consumers, and the degree of intellectual property protection, but also the internal incentives for obtaining subsidies through social capital investment. Then, according to the data of strategic emerging enterprises from 254 listed companies, they found that double failure of market and government may be the source of the problem. Under the same condition, the enterprises with social capital investment achieved nearly half more government subsidies than other enterprises. This was reflected that enterprise's social capital investments might be hidden for the exchange of government subsidies under the current system background. Enterprise's social capital investment depended on the capability of government intervention, rather than the ability of competing with others in market. The government subsidies distorted the enterprises' in- 
vestment behavior. Enterprise's social capital investment weakened the effect of government subsidies on encouraging innovation. The government should re-examine the policy of government subsidies, perfect the system quickly, shift the focus to the real key point practically and explore the exit mechanism gradually.

\section{2) Financial Supporting Policy}

Cultivating and developing strategic emerging industry is the key point of promoting China's social and economic sustainable development at present. Financial support plays a key role of the core and foundation in fostering strategic emerging industries. Gu, H.F. (2011) [9] [10] proposed finance supporting frame and system for the developing of strategic emerging industries, which would render important theory guide and strategy reference to China establishing scientifically high-efficiency industry development policy and finance economic policy. Wu, J.X. and Li, X.Z. (2012) [11] argued that the local governments should take more active roles to response to market failure, commit to strategic mission, construct regional innovation system, and take advantage of opportunity window during the development of strategic emerging industries. And they proposed suggestions that included soliciting the support of central government, fostering the local big enterprises, helping to build industrial ecosystem, promoting to the establishment of non-profitable industry research labs, leading consumption, which would give the beneficial reference to policy formation from the local governments. Using the data of 112 listed companies from 7 strategic emerging industries and based on the DEA efficiency measurement form 2009 to 2011, Zhai, H.Y. (2012) [12] found that the mean overall efficiency, pure technical efficiency and scale efficiency were growing in 2011 compared to 2010 and 2009. The equity financing efficiency of energy saving and environmental protection, new energy, new materials and IT industry increased much, while the equity financing efficiency of high-end technology and equipment industry showing no growth, but was still at a high level though, and the equity financing efficiency of biological and new energy automotive industry decreased slightly. After examined by Logit model, it was found that the listing of the company was conducive to maximize the value of strategic emerging industries, but the debt financing behavior had a negative impact on the efficiency of financial support. Based on a survey of 15 commercial banks in Shanghai, Chen, C. (2013) [13] found that the banking sector had significantly strengthened financial innovations for strategic emerging industries, and had launched a series of innovative measures on institutional mechanisms, product design, business model, and risk control. Some issues such as the inner motivation of the banking sector in supporting strategic emerging industries and intellectual property pledge loan had been solved. The franchise financial institutions which focus on high science and technology had been established. However, there was a structural conflict between the banks' internal credit process management and the development of strategic emerging industries, the application and spread of innovative products are lack of policy support from the government departments, and the spread of innovative business models is lack of coordination of guarantee agencies, so that there are still some problems in supporting the development of strategic emerging industries.

\section{3) Industry Policies}

Concentrating on the special case-industrialization of synthetic ammonia in the technological innovation history, Zhou, C. and Zhou, H. (2011) [14] discussed it with multiple perspectives and emphasized to answer two questions: How did synthetic the innovation process and ultimately come into industrialization? Ammonia industry span the valley of death in what enlightenment did synthetic ammonia industrialization left us for China's cultivating and developing of strategic emerging industries?

Liu, C., Gu, Q. and Dong, R.Q. (2011) [15] discussed how the industry policies play an active role in the development of strategic emerging industries in China based on the experiences of the developed countries. They believed that the industry policies should focus on market cultivation, scientific and technical innovation, rational distribution, implementation means, and implementation strength. Li, K. and Chen, L.J. (2012) [16] compared the different focus of the world's major developed countries in the emerging industries of strategic layout and support policies analyzed the similarities and differences of China's major provinces in the choice of strategic emerging industries. Based on the concept of "innovative 2.0", we proposed the double helix model of the development of strategic emerging industries and the supporting policy system diamond model. Finally we also proposed a solution proposals and measures to promote Chinese strategic emerging industries.

\section{4) International Experience Reference}

Hu, H.F. and Hu, J.Y. (2011) [17] mainly compared and analyzed three types of financing mechanisms in strategic emerging industries, which were a market-dominant type in America, a bank-dominant type in Japan and a universal bank-dominant type in Germany. Learning form those financing mechanisms, they considered that China should build the financing mechanism of strategic emerging industries supported by government pol- 
icy and bank financing, develop a multi-level capital market, and establish a corresponding supervision system to ensure the flow of funds safe.

In the second half of the 19th century, the United States focused on the development of iron and steel industry which was one of strategic emerging industries during that period, based on large-scale domestic demand for industrial products with the help of a series of trade protection and industrial promotion policies including high tariffs, restrictions on FDI, enhancement of personnel training, and rational exploitation of natural resources. As a pursuer of Britain at the beginning, American seized the opportunity of the third wave of technological revolution and realized the industrialization and economic development depending on strategic policies of supporting national industries, unique national innovation system, continuous progress of technologies, intensive use of high-quality capital equipment, productivity advantages of high-wage workers and effective exploitation of natural resources. Jia, G.L. and Yang, W. (2012) [18] believed that this successful experience provided China with important guidance for how to develop contemporary strategic emerging industries based on domestic demand and to establish the development model of endogenous growth and driven by innovation. Xue, L., Lin, Z.L., Liang, Z., Chen, L., Zhou, Y. and Wang, X. (2013) [19] systematically examined the development trend and characteristics of strategic emerging industries around the world from five perspectives: driving force, development goals, development patterns, major actors, and cooperation and competition structure. Then they investigated the state of industrial development in major countries, including United States, EU countries, Japan, Korea, Brazil, India and Russia. The national strategies, development goals and targeted policies for strategic emerging industries in these countries were also put into analysis. Based on the study they summed up the implications for China.

From the perspective of the industrial development history, strategic emerging industries aren't new things, which mean that every era has its own strategic emerging industries. Based on lifecycle theory and industrial evolution theory, Wang, S.Y., Huo, G.Q., Sun, H. and Yang, Y. (2014) [20] analyzed the developing process of the automobile industry of United Kingdom and the information technology industry of American. The analysis results showed that, as the primary stage of strategic industries, the lifecycle of strategic emerging industries underwent the vibrating period because of the impacts of different factors, such as "Zooming-Slowing downZooming", "Zooming-Ceasing-Zooming" and "Zooming-Declining-Zooming”. And the key successful factors that influenced the evolution of strategic emerging industries contained industrial environment, government support, industrial innovation, industrial platform, risk control and the cultivation of the industrial chain and industrial cluster, which facilitated the evolution of strategic emerging industries synergistically.

\subsubsection{Research on Problems about Industries Growing}

\section{1) Industries Selection}

Relying on evaluation model, which is established based on AHP and fuzzy comprehensive assess methods, He, Z.C., Zhang, X. and Zhou, Z.H. (2010) [21] considered the feasibility of advancing strategic emerging industries was of assist to select and appraise these new ones comprehensively, accurately, and objectively. And they employed above model to demonstrate the evaluation and selection of auto manufacturing industry of new energy automobile in Hunan Province.

Strategic emerging industries deeply combine emerging technology and industry. They represent not only direction of technological innovation, but also the direction of industrial development. With features such as only the strategic, inter-connecting, growing, innovative, risky and oriented, Liu, H.C. (2011) [22] pointed out the selection of strategic emerging industries should fully show these features and follow the principles such as state will, market demand, technology innovation, industry interconnection, employment obtaining ability and sustainable development. Since each region's economic development and social environment is diverse, how to select and develop emerging industries reasonably is of strategic importance.

Series of strategic emerging industries characterized by new technology and new markets sprung up after the financial crisis of 2008. As for one country, how to choose and sustain strategic emerging industries is of great meaning. He, Z.C. and Wu, Y. (2011) [23] constructed the index system and evaluation model of strategic emerging industries and executed industrial assessment and selection. They filtered indices in line with four characteristics of strategic emerging industries and then took the example of Hunan province to illustrate by making use of Weaver-Thomas model. The weaknesses of AHP, IE, PCA and other selection theories and methods were analyzed during the application on strategic emerging industries. According to the specificity of selection and evaluation in strategic emerging industries, Hu, Z.H., Li, C.Q. and Xiong, Y.Q. (2011) [24] built the 
corresponding indicator system. And then based on the combination weights- "AHP-IE-PCA", the selection model of regional strategic emerging industries was tentative proposed, which was applied to $\mathrm{N}$ county in the selection and evaluation of strategic emerging industries.

Through analyzing the impact factors and performance between the strategies of leading and following of entry the strategic emerging industries, Guo, X.D. and Song, W.J. (2011) [25] attempted to figure out how reasonable lead enterprises to enter the industries as early as possible. The results demonstrated that, the developing prospect and expected profit could attract enterprises to enter these industries. Meanwhile, the bigger undispersed risk and stronger change in policy and regulations an industry had, the more likely for an enterprise to enter this industry as a leader. The enterprises which entered the industries as leaders could have better performance in the ability of asset management and profitability. In addition, the timing of entry, the structure of property ownership and enterprise scale had an interactive effect with the performance level of an enterprise. Based on the conclusions above, they put forward some policy advices on guiding enterprises invest into the strategic emerging industries effectively.

Through a careful examination of the choices of regional strategic emerging industries, Liu, T. and Wang, J.Y. (2012) [26] concluded that, a couple of problems were manifest, particularly the lack of thorough consideration in choices and the excessive convergence in choices across regions. They analyzed three major causes: firstly, lack of empirical and comparative study on the choices of regional strategic emerging industries; secondly, lack of dialectical thinking and risk assessment on strategic emerging industries; thirdly, lack of coordination among different regions. In order to solve these problems, they pointed out that from the perspective of technological economics, a model should be designed, and a scientific evaluation as well as a comparative analysis of choices should be conducted; from the perspective of policy countermeasures, a number of mechanisms should he improved. To begin with, the coordination mechanism should be improved by way of improving top level design and three-dimensional allocation of resources. Another mechanism that needed to be improved was that of market regulation and control. Besides, risk analysis and assessment mechanism should also be improved with the help of dialectical thinking. Management mechanism was an area that especially needed improvement by combining support and regulation. Finally, policy regulation and control mechanism should be improved by fusing stimulation and restriction.

To solve the problem of "over convergence" on the selection of strategic emerging industries in China, Wang, C.W. (2013) [27] traced the theoretical origins of this policy, and found out that, both Developmentalism and System of Innovation theory are kinds of institutional or technological determinism, which finally led to or at least acquiesced in this convergence. They considered the selection could only be successful under the circumstance of the vision constructed by institution or technology, the cohesion between the elements' interaction in system, as well as the constraint of artifact and material conditions. Although it was very difficult for China to meet all these requirements, still the tradition of policy experimentation could be recovered as a good start-point to release the potential energy of local government and other actors, where the unclarity of administrative guidance was very helpful and important to have the necessary interpretive flexibility.

\section{2) Evolutionary or Developing Path}

Aiming at the twin missions appearing in the upgrading of traditional industries and cultivating and developing of strategic new industries faced by China's industry development, Xiong, Y.Q. and Li, S.C. (2010) [28] constructed the theoretical model on coupling development of strategic emerging industries and traditional industries, analyzed the coupling relationship and coupling contents theoretically, and studied the coupling process and coupling function mechanism of strategic emerging industries and traditional industries.

Economic recession of long-wave can gestate technological revolution; technological revolution can cause emerging industry. Zhang, G.S. (2012) [29] stated that this financial crisis was gestating a new technological revolution, and caused a new chance of emerging industrial revolution; however, the strategic emerging industries in China were still in germination. He emphasized that developing strategic emerging industries rapidly need focusing on technological revolution, accelerating the paradigm shift through designing an arrangement of effective management, innovating industrial policies, paying attention to the matching of policies coordination and industry dynamics, strengthening the joint development of the emerging industries, promoting the construction of the ability of policymakers.

In today's blue economy era, the marine strategic emerging industry has become the strategic commanding point which the maritime power fighting for. Li, J. and Liu, X.F. (2012) [30] proposed the developing path of marine strategic emerging industries in Fujian Province of China. He, Z.C., Wu, Y., Zhang, M. and Wen, X.M. 
(2012) [31] studied the convergence of producer service and strategic emerging industries in China, found that the convergence degree of the two industries was unbalanced.

The selection and development of strategic emerging industries essentially means seizing the current and future industry opportunity that causes the revolutionary changes in factors of production in economic systems. Zhang, S.R. (2012) [32] stated the convergence with strategic emerging industries is the path of agricultural industrialization of deepening development.

Based on the analytical framework of evolutionary game theory, Lu, L.J. and Yu, B.B. (2012) [33] explored evolution stages, corporate behavior and government policy in the integration of development of the traditional industries and strategic emerging industries, and take Shaoxing in Zhejiang Province for example by empirical analysis on above-mentioned theory. The results showed that the traditional industries and strategic; emerging industries of integration of development consists of three stages, including the corresponding stage of each other coordinate the development stage and alternative stage of differentiation; strategic choices of local government and key enterprise impact on the degree of integration and evolution trends of traditional industries and strategic emerging industries; local government in the elimination of backward production capacity of traditional industries, increasing funding for strategic; emerging industries and building innovation as the link between the two platforms play an important role. Chen, Y.T., Cheng, P. and Liang, Z. (2012) [34] put forward the theoretical framework of two-stage analysis for the evolution of strategic emerging industries to explore the influential factors from four dimensions, which consisted of technological-open innovation vs. indigenous innovation, market demand-domestic market creation vs. international market, industry players-Incumbents vs. entrants, institutional-policy-driven or market-driven. Based on this theoretical model they utilized the case of Wind Turbine Manufacturing Industry, to analyze the evolution process of Chinese case from 1980 to 2011, and explored the influential factors.

Nowadays, the most evident trend in economic; development is the integration between services and manufacturing. Based on such doctrine as industrial symbiosis, division of labor and production value chain theory, He, Z.C., Wu, Y., Jiang, J.L. and Chen, Y.M. (2013) [35] deduced development mechanism and integration relationship of producer services and strategic; emerging industries form perspectives of scholars as well as integration practices evaluation of the service industry and manufacturing at home and abroad. By introducing the input-output mechanism 1 model, we design indices concerned industry interaction and integration, to analyze internal working between producer services and strategic; emerging industries. However, after empirical analysis on evaluating the whole country as well as Jiangsu Province, Hunan and Shanxi Province, we detect that the interaction and integration effects is insignificant in China. Thereforth, China's producer services and strategic emerging industries should transfer its manufacturing economy to service economy, so that both of which would reach the high ends of the "smile curve". Wang, K.K. (2013) [36] stated the evolution strategy of general developing process of strategic emerging industries and proposed "multi-step" developing path of strategic emerging industries in China based on Karl Marx's theory of resources allocation. He also emphasized that the implementation of "multi-step" promotion strategy of strategic emerging industries need optimizing the interaction of market regulation and government adjustment; promoting the positive interaction and coordinated development of the activities of advancing traditional industries, introducing and absorbing foreign technology and innovating original technology; meanwhile, focusing on the re-innovation during the course of introducing and absorbing foreign technology and the technological leapfrogging in the course of upgrading traditional industries, and then realizing the effective connection of different "steps".

The cultivation and development of emerging strategic industries has opened "the window of opportunity" for the traditional industries. Xiong, Y.Q. and Yu, Y. (2013) [37] analyzed the decision-making influencing factors about traditional enterprises docking to the emerging strategic industries; also put forward "two patterns and four paths". The two docking patterns were "high-road" and "low-road", and the four specific matching paths were "transformation butt-joint", "upgrading butt-joint", "relation butt-joint" and "radiation butt-joint". They established the decision-making model about traditional enterprises docking to the emerging strategic industries and took 10 traditional enterprises in "A" region for an example to verify the effectiveness and feasibility of the decision-making model, which provided a new thought for matching and docking the traditional enterprises and emerging strategic industries. Jiang, H. (2014) [38] pointed out that the system of strategic emerging industries is an open complex system whose evolution development process is the process of resource allocation, which has many uncertainties. These uncertainties show that self-organizing mechanism of the system yields nonlinear interaction among the subsystems at the micro level under outside control variable such as resource characteri- 
zation, capital, technology, industrial policy, investment and finance policy and industrial chain of matching. It determines the threshold of system instability and the unstable branch of ways. After technology innovation has been turned into prototype products, the system wins in dominant design competition if the system exchanges material, energy and information from the external world. Its macro-structure will occur to mutation, the system changes from disorder into order, and the low order into the high order. And then the trend that strategic emerging industry has developed into the forerunner industry and the pillar industry is not reversible. Government support policies should be a choice to make.

\section{3) Growth Mechanism}

Liu, Z.Y. (2010) [39] analyzed the basic characteristics and forming process of the dominant design of strategic emerging industries, and put forward six factors influencing the dominant design of strategic emerging industries, including system technical superiority, upgradeability, governance capabilities of alliance, the original number of users, catalysis of financial capital and the role of government. He put forward technology standard promotion strategy, alliance strategies and control strategies.

The dominant form of strategic emerging industries organization is modular contract network organization, specifically including three types of enterprise organizational form such as module-maker, integrator and designer. Xiao, S.G. (2011) [40] considered that the distribution between labor and capital in strategic emerging industries organization divides into two levels: The first level is the distribution of after-tax value added (namely $\mathrm{V}+\mathrm{M}$ pan after-tax) with intermediate products piece-work contract way in industries organization levels by taking the labor and capital as a whole (appears as different business entity distribution subject). The distribution pattern is: three types of enterprise's after-tax value added income increases rapidly and significantly in order of module-maker, integrator and designer; The second level is the distribution of after-tax value added in enterprise level based on the first level distribution by labor and capital group. This article analyzes that the three types of enterprises should execute different labor and capital distribution paradigm: the module-maker adopts the distribution paradigm led by physical capital, the integrator adopts the distribution paradigm led by human capital and physical capital both and the designer adopts the distribution paradigm led by human capital. The labor and capital distribution in three types of enterprise has big distinction such as identity, status, income models, distribution basis, distribution order and the governance system arrangements of distribution guarantee, this article also discusses them systematically. Zhou, H.Y., He, Z.C. and Zhang, X. (2011) [41] probed into the inner mechanism of upgrading between strategic emerging industries and industrial structure optimization and upgrading in China, then analyzed the countermeasures of developing strategic emerging industries. Qiao, X.N. and Li, H.S. (2011) [42] researched the growth mechanism of strategic emerging industries in China based on the experience of sewage treatment industry, and gave conclusions as follows: first, the growing process of strategic emerging industries is a complex evolution system which both internal conditions and external environment have impact on; second, the cultivation of strategic emerging industries should base on actual conditions of China, such as factor endowment structure, competition environment, political governance model and other factors; third, the policy system of fostering strategic emerging industries should include competition policies, demand policies, and investment and financing policies. Liu, K. and Han, L.M. (2012) [43] analyzed the internal and external factors, action mechanism and main paths of the formation of marine strategic emerging industries.

Xiao, X.Z., He, W.T. and Guo, X.D. (2014) [44] traced dynamically the survival situation of 494 enterprises entering strategic emerging industries by event history analysis method, described the temporal distribution characteristics of enterprises' survival through KM (Kaplan-Meier) estimate method, and analyzed the impact of competence accumulation and expansion behaviors on the duration of enterprises' survival using stratified Cox risk model based on $\mathrm{R} \& \mathrm{D}$ behavior variables to dissect the survival state of strategic emerging industries and to explain how enterprises exist sustainably. Their research results showed that enterprises' competence accumulation had dramatic impact on the duration of enterprises' survival; enterprises' R \& D competence accumulation was the most important factor that influenced enterprises' sustainable survival; the duration of enterprises' survival can't be extended by the improvement of enterprises' operation competence and market competence separately, however, the interaction of operation competence and market competence would take a positive effect. This conclusion expanded the knowledge of enterprises' competence in the resource-based view of firm, that is, the diversified enterprises' competence combination consists of an important part of industry growth mechanism. And they also concluded that enterprises' expansion behaviors influenced the duration of enterprises' survival, during different phases of product life cycle, the current scale expansion of enterprises reduced the risks of enterprises' exit, however, the rapid expansion constituted a threat to enterprises' sustainable survival. Based on 
the above research conclusions, they put forward the following countermeasures: firstly, help enterprises decrease operation costs to reduce the risks of enterprises' exit; secondly, promote the dual-wheel driving of enterprise technology innovation and business model innovation to improve the quality of enterprises' survival; thirdly, guide enterprises to reduce blind investment and expansion so as to lower industry fluctuations and ensure benign expansion of strategic emerging industries.

\section{4) Developing Mode}

Strategic emerging industry is the hot point of the world, and it is also the focal point for future of China and the world. Liu, X.L., Gao, W., Lv, P. and Cheng, P. (2012) [45] presented the development model of photovoltaic industry in five dimensions: profound globalization, competing on the industry frontier, joint efforts of central government and local government, strategy of technology platform, cultivating industrial cluster and industrial chain. Chinese photovoltaic industry can serve as a good example for other strategic emerging industries. At the same time, they found the photovoltaic industry is facing with many new challenges, such as being too relied on the policy and international market, facing with excessive competition, etc. Their conclusion is that the development of photovoltaic industry indicated a new way for strategic emerging industry. There should be a new thinking model only with which China can promote the development of strategic new industry rapidly.

How can strategic emerging industries prevent from being locked in low end? Liu, Z.B. (2012) [46] built an analysis framework based on "chain" and seeking for polices to promote strategic emerging industries in five aspects, including industrial chain, value chain, innovation chain, service industries chain and ecological chain. Their suggestions of the national competitive strategy in the post-crisis period are: first, absorb high-end oversea production factors taking advantage of domestic demand; second, join in the high-end sector of global intra-product specialization; third, develop knowledge-intensive sector of service industry chain.

Strategic emerging industries have become one of the main engines to ensure the sustained economic growth in China. The development of strategic emerging industries and the development of modern service industry are not in contradiction and the development of strategic emerging industries can optimize the structure of productive service industries and promote the innovation of productive service industries. The development of productive service industries can provide the guarantee for developing strategic emerging industries and accelerate the development of strategic emerging industries. Yang, Y.W., Zheng, J.H. and Huang, Y.C. (2012) [47] constructed a model that indicates the strategic emerging industries and productive services can be in coordinated development, put forward research propositions, and then made an empirical test on the strategic emerging industries and productive services. Huang, Y.C., Zheng, J.H., Tan, H.B. and Yang, Y.W. (2012) [48] defined the concept of strategic emerging industries, analyzed the evolution path of strategic emerging industries, and then took the flat panel displays as example combined with the evolution path of strategic emerging industries and catch-up ability of backward area study the catch-up path and time choice of backward area to development strategic emerging industries, aiming at guide backward areas to seek opportunities in strategic emerging industries thus achieve the transformation from capture-based governance model to balanced-type model in the global value chain.

Strategic emerging industry defined as an industry in the early stage of industrialization has a significant, long-term impact on the country or region. It can trigger the economic development for the country or region. Meanwhile it bears the characteristics of being directional, external innovational, risky and regional. Difficult and risky as its development is, Lin, X.J. (2012) [49] stated that most enterprises comprise a new industry through de alio entry from the high-tech industry, de novo entry from traditional industry or fusion of high-tech and traditional industries, but most enterprises are abortive and difficult to form industry. So the government should focus on the special characteristics of the emerging industries, strengthen the leading role and support of policy in an effort to form strategic emerging industries with national and regional characteristics. Shen, J.X. (2012) [50] innovate the industry-university-institute cooperation mode, and implement the transform from enterprise technology based needs to industry technology based needs, from point-to-point distributed cooperation to network integrated cooperation, from one-way transfer of technical knowledge to two-way interaction, from contractual operation total-in-one cooperation is the fundamental way to make the breakthrough in industry key technology and promote the core competitiveness of emerging industries. In order to construct the strategic emerging industries development based industry-university-institute cooperation, not only need to clarify the target and emphasis of industry-university-institute cooperation according to character of strategic emerging industries in different development phase; but also need to make a technology roadmap for strategic emerging industries scientifically, promote the initiatives and ability of enterprise to innovate, make an effort to create a diverse regional emerging industry network, and strengthen the policy guidance and market cultivation. 
Based on the theories of business ecosystem and national innovation system, this paper put forward the concept of industrial ecosystem. Quite different from the ecologist or environmentalist who regards industrial ecosystem as an environmental ecosystem with the circle of material, energy and information, Li, X.H. and Liu, F. (2013) [51] defined industrial ecosystem as a set of factors that are vital to the development of a certain industry and their interrelationship. The industrial ecosystem consist of 3 sub-systems including innovation ecosystem, production ecosystem, and application ecosystem, and subsidiary factors including factors supply, infrastructure, socio-cultural environment, international environment, policy system. The industrial ecosystem is characterized of interdependencies, complex interactions, self-recovery, and co-evolution. The development of an industry is the result of the reaction of the whole industrial ecosystem. The competition in strategic emerging industries among countries is indeed the competition in their industrial ecosystems. The country which firstly set up perfect industrial ecosystem could take the preemptive opportunities. In order to cultivate and prompt the strategic emerging industries, the policies could not only be concentrated to one factor, but also be focused on prompting the whole industrial ecosystem's perfect and harmony.

The high-end development of strategic emerging industries can help to transform the economic development mode and promote industrial upgrading. Based on the listed companies' data, Ren, B.Q. and Wang, L.L. (2014) [52] used the methods of DEA (Data Envelopment Analysis) and Malmquist Index to measure change rate of TFP (Total Factor Productivity) and its decomposition. From the analysis, they found that the change rate of TFP showed a decreasing trend both in whole industry and industry classification, and it mainly caused by the drop of technical progress and pure technical efficiency. So strategic emerging industries showed a "ignore the technological innovation and attached importance to the scale expansion" low-end trend. From both whole industry and industry classification the following regression analyses empirically examine the trend and the influencing factors in change rate of TFP and its decomposition. Our regression results confirm the low-end trend in strategic emerging industries.

\section{5) Industry Cluster}

Yu, D.K., Tu, G.P. and Chen, H. (2012) [53] analyzed feasibility and necessity of cooperation development of strategic emerging industry cluster from comparability of resources and culture and conducing to forming of support industry and building of regional innovation system, analyzed three paths including value chain, knowledge chain and internet of things of the industry cluster, put forward the patterns of single-core, multi-core and none-core of the industry cluster, and then advanced some strategies to boost cooperation development of the industry cluster.

Industrial clusters are a success mode promoting strategic emerging industries developing fast. It is the importance that agglomeration effect and its influence factors of China's high-tech zone is studied to speed up the strategic and emerging industry development. From the perspective of industrial organization, Zhao, Y.L. and Shi, F.F. (2012) [54] conducted a questionnaire survey about Wuhan Biolake, the results of statistical analysis revealed four factors which can affect the agglomeration effect of Biolake, they are enterprise agglomeration factors, personnel flow factors, organizational factors and industry ecological factors. Further build regression model, then according to the result of regression analyzing mechanism of every factors, constructing optimization model of industrial organization to enhance the agglomeration effect of strategic emerging industries.

To construct the ecosystem of cluster brand in strategic emerging industries is beneficial for the local government and enterprises to establish and develop cluster brand in strategic emerging industries. With progressive application of literature review focus group interview and empirical study, Wang, Q.W. and Wang, X.Y. (2013) [55] constructed an ecosystem of cluster brands in strategic emerging industries, consisting of 8 categories and 33 key constituents, and then tested and verified the relations among those constituents. The results showed that the macro-environment constituents, industry constituents, resource constituents and supportive constituents had a positive influence on the cluster constituents; the macro-environment constituents, industry constituents and cluster constituents had a positive influence on the enterprise constituents; the enterprise constituents had a positive influence on the market constituents; and the competitor constituents had a negative influence on the enterprise constituents.

It has long been argued the impact of industrial agglomeration on FDI technology spillover, but its mechanism is very little discussed. Based on the FDI technology transfer model by Wang \& Blomstrom (1992), Li, S.L. and Chen, Z.W. (2014) [56] targeted strategic emerging industries during transition and studied the mechanism how emerging industrial agglomeration affects the FDI technology spillover. They also used the layer data of companies in the emerging industries in China from 2006 to 2011 to prove their improvement effect on the FDI 
technology spillover when companies in the same industry agglomerated in the county level. They also found that the growth of agglomeration level had non-linear relationship with its improvement effect. The number of agglomerated companies had the most impact of improvement, following by the market size agglomeration, and the agglomeration of employment had least impact. With regards to China's emerging industries development, there was still space to further improve the companies' agglomeration, market size agglomeration should also be considered but agglomeration of employment needs to be controlled urgently.

Industries colony is one of the most important marks of the formation of strategic emerging industries which is also the effective mode of its development. According to the academic statues, the formation mechanism research of the related industries is what all sectors of society focus on. Zhang, Z.H., Huang, H.X., Xie, Z.Q. and Sun, L.J. (2014) [57] set Wuhan Optics Valley of China as example to analyze the formation mechanism of strategic emerging industries. Researches showed that the formation mechanism of strategic emerging industries had a character of diversification, which was not simply a dynamic thought process but a systematic thought process. Especially the systematic thought process of regional innovation system and the industrial innovation system, they had a distinct feature of self-dependent innovation. Comprehensively analyzing the outcome data they suggested it was necessary to fully utilize the effect of the government, market and other subjects and adopt compatible developing mechanisms based on the actual features of the strategic emerging industries, for the sake of the development of strategic emerging industries colony.

\subsubsection{Research on Technological Innovation}

Luan, C.J. (2012) [58] explored measuring indicators of generic technology of strategic emerging industries including the ratio of technology co-occurrence, technology co-relationship, centrality-multiple measures-degree, degree centrality, betweenness centrality, which were of great significance to select and manage generic technology during the developing process of strategic emerging industries.

Emerging-technologies and technology-intensive are the important features of strategic emerging industries. To establish the identification and quantitative evaluation standards for the technical characteristics of strategic emerging industries is important. How to measure and evaluate the technical characteristics of the strategic emerging industries has yet not to see the related results. To describe the technical characteristics and make the specific evaluation standards of strategic emerging industries, Huang, L.C, Wang, K.K., Wu, F.F., Miao, H. and Lou, Y. (2012) [59] attempted to select three indicators of ratio of R \& D personnel, R \& D investment intensity and patent applications per $100 \mathrm{R} \& \mathrm{D}$ personnel, and proposed recommendations to enhance the technical characteristics of the strategic emerging industries. Yu, J. and Chen, K.H. (2012) [60] pointed out that a series of statistic analyses based on documents of representative patents showed that the development performance of technological innovation performance of Chinese seven strategic emerging industries was becoming better in contrast to multi-national enterprises in China; however, there was big difference across them in the technological innovation capability. After nearly ten years of rapid catching-up development Chinese local enterprises gradually shared a bigger proportion of technological innovation outputs in electronic and communication field. In contrast, a bigger share of technological innovation outputs in the hybrid electric vehicle industry was dominated by multi-national enterprises, especially from Japan, America and Korea, in China. The findings indicated that some strategic emerging industries would face tremendous challenges in technological development to confront the competition of multi-national enterprises in China. It was difficult for them to expectedly and quickly occupy the commanding height of technological and industrial development by look-ahead deployment.

Using Stochastic Frontier Approach (SFA) and based on the panel data of strategic emerging industries from 2003 to 2010, Lv, Y.W. and Sun, H. (2013) [61] analyzed technical efficiency and influencing factors of 18 sectors of China's strategic emerging industries. The result showed that the technical efficiency of China's strategic emerging industries was low, and presented an undulating characteristic. The technical progress rate of China's strategic emerging industries was fast, but presented downward trend. Heterogeneity existed in China's strategic emerging industries, and the technical efficiency in different industries was different obviously. In exogenous factors, firm size and industrial agglomeration had positive effects on technical efficiency of China's strategic emerging industries, while FDI and the proportion of state-owned economy had not.

The development of strategic emerging industries needs to build the innovation ecosystem. The core enterprise of innovation ecosystem is generally responsible for the development of the core technology of the product platform, and needs to delegate the peripheral accessory products' research and development tasks to the agency organization. The core enterprise needs to design contracts to incentive the agency organization's knowledge 
inputs at the research and development stage of the peripheral accessory products. According to the research, Wu, S.B. (2013) [62] pointed out that the core enterprise's ability of profit transferring, task correlation of research and development, task observation all have great influence on the contracts designing.

The innovation effects and industrial competitiveness have long been neglected in innovation research of strategic emerging industry. Applying SFA method, Wu, L. and Zhang, Y.G. (2013) [63] made a comparative analysis on the innovation efficiency of Beijing IT and pharmaceutical industries that are two representative industries of Beijing strategic emerging industries. Divide innovation efficiency into the technological innovation efficiency and the innovative products transformation efficiency. The result showed that the innovation efficiency of IT industry improved rapidly by years, but the level and configuration of scientific researchers became the bottlenecks, which was not conducive to the development of industrial high level innovation. The pharmaceutical industry, although had the higher efficiency of technological innovation, had low innovative products conversion efficiency, and the industry was lack of market competitiveness and innovating motivation. Sun, Y.T. and Li, M.M. (2013) [64] explored the local factors which including FDI, the economic development, the science and education policy, the regional location, how to impact on the enterprises' technological innovation capability. The sample for empirical study is 212 enlisted companies in China's strategic emerging industries and 68 prefecture-level cities. Using the model of negative binomial regression, this study shows that the higher level of regional economic development and the more significantly advantage of regional location, the more beneficial to improve the enterprises' technological innovation capability in China's strategic emerging industries, on the contrary, the level of regional FDI has a significantly negative impact on the enterprises' technological innovation capability, and also the regional science and education policy has not a significantly impact on the enterprises' technological innovation capability.

Based on the enterprise questionnaire of seven national strategic emerging industries, Xing, H.P. and Wei, P. (2013) [65] employed statistical empirical method to analyze firms' behavior pattern of technological innovation from three aspects, i.e. the industry they belong to, economic nature and scale. Their research results revealed that: digestion, absorption and innovation are the main innovative approaches of strategic emerging industries in China, and too rapid flow of R \& D staff is the main problem for firms' R \& D team; the R \& D intensity of state-owned enterprises is the lowest, but their input in fundamental researches is the largest; the larger the scale of firms is, the greater the innovation fund they get from the government would be, and the stronger their innovative capacity would be, while the weaker their R \& D intensity would be. Finally, this article proposes the corresponding measures and suggestions for the government to encourage and guide technological innovation of strategic emerging industries.

Strategic emerging industries are the convergence of emerging technologies and emerging industries and are the important opportunity for developing countries to implement Forging Ahead Strategy. Emerging technologies are the competency or core for the industrial development and emerging industries are the bridge for introducing the emerging technologies to the new market. Yue, Z.G. (2014) [66] pointed out that collaborative development of technical chain and industrial chain was the key factor for the growth of strategic emerging industries; the theoretical exploration and practices of IOT industry testified that autonomous technical chain should be constructed by the strategy of patent and standard to avoid the technical hollowing-out and should be developed by the innovation of business model to avoid the worthlessness of technical innovations.

Using the data of strategy emerging industry listed companies from Shenzhen Growth Enterprise Board, Li, Y.H. (2014) [67] investigated the effects of corporate governance on the heterogeneity of corporate R \& D innovation. The findings indicated that the CEO serving as managing director was positive with corporate exploratory research and innovation; and the VC holding stocks had a positive effect on corporate routine innovation, while the ownership concentration and VC holding stocks were all negative with corporate exploratory innovation; the managerial compensation will promote both corporate exploratory innovation and routine innovation.

Focuses on the problem of enterprise partner selection for generic technology development in strategic emerging industries, Xiong, Y.Q., Bai, Y. and Chen, X.H. (2014) [68] identified a cooperative enterprise selection model of double-dimension and two-phase based on the "individual" and "relationship" dimension. Then the "first-round selection" aimed to choose some finalist enterprises by using the method based on MCDM and ameliorated multi-objective optimal decision and the "dynamic adjustment" phase established the dynamic screening of enterprises by constructing a cooperation capability-performance matrix model. The cooperative enterprises were divided into "motivated type", "balanced type" and "suspended type". Finally an example applies the model to verify its rationality and operability, providing a practical approach for enterprise partner se- 
lection on strategic emerging industrial generic technology development. Wu, J.L. and Wang, H.Q. (2014) [69] analyzed the technology innovation characteristics and the power and resistance to achieve significant technology breakthrough of strategic emerging industries from the modularization perspective, and built radical technology innovation paths of strategic emerging industries: the path for peripheral module to move the high end, the path to break through key module, the path to subvert and reconstruct the structure \& rule, and the path for module and structure to coupling upgrade. Based on synthesizing theoretical analysis and case study, they gave out the difference and applicable condition among the four paths.

\subsubsection{Research on Measurement or Evaluation}

1) Competitiveness, Performance and Structure

With the low-carbon economic development, Tan, R.J. (2012) [70] investigated the content and form of regional strategic emerging industrial competitiveness, made a structural equation model covering strategic support, innovation capability, growth potential and other nine factors and put the empirical test to explore the enhance and internal mechanism of regional strategic emerging industries. The results showed that innovation capability and growth potential were the two significant factors of regional strategic emerging industry competitiveness.

Ling, J.H. and Hu, W.R. (2012) [71] made a sub-industry comparative analysis of the impact of the firm size and capital structure on operating performance with the sample of listed companies of Guangdong province. Based on different characteristics between traditional industry and strategic emerging industry, they found that: (1) Scale expansion went against the operating performance of traditional industries but benefited that of strategic emerging industry; (2) Equity financing weakened the operating performance of traditional industries, but significantly improved that of strategic emerging industry. The results of their study showed that strategic emerging industries should be fully supported considering the internal IRS (Increasing Returns to Scale). Equity financing will be more efficient.

Zhang, R. (2014) [72] established an evaluation system adapted to the business objectives and management philosophy of strategic emerging industries, and put emphasis on major technological innovation and breakthrough capacity evaluation, as well as highlight the role of characteristics of "strategic", "emerging" and the law of circular economic development in business performance evaluation.

By using Chinese strategic emerging industries panel data from 1998 to 2010, Cheng, G.S. and Zhu, H.J. (2014) [73] constructed a theoretical model and analyzed empirically the factors which influenced the market performance of private enterprises to develop strategic emerging industries. The result showed that the number of employees, export delivery value, the output value of the state-owned enterprises would have a negative impact on the market performance of private enterprises, whereas gross output value of industry, R \& D funds and production would have a positive influence on the market performance of private enterprises, providing a useful reference for the government departments to promote private enterprises to enter and develop strategic emerging industries.

\section{2) Efficiency, Importance and Scale}

Wang, J. and Zhang, Z. (2014) [74] compared strategic emerging industries with leading industries, pillar industries, and high and new technology industries from industry characteristics and evaluation of development efficiency; and proposed an evaluation framework of the development efficiency of strategic emerging industries. Based upon the classification on 22 kinds of rare minerals in six categories and the analysis on the important uses of each rare mineral in strategic emerging industries, Li, P.F., Yang, D.H., Qu, S.N. and Zhang, Y.F. (2014) [75] gave a quantitative strategic assessment on rare minerals from three dimensions of supply risk, environmental impact and economic impact of supply restrictions by 9 indicators. The result from available data indicated that the platinum group metals have the highest strategic importance among 22 kinds of rare minerals while the strategic importance of cesium is the lowest. The uncertainty analysis by Monte Carlo method further verified that the result of assessment was of enough reliability. Given the rising importance of rare mineral recourses as critical raw materials in strategic emerging industries, the Chinese government should step up to develop and implement National Rare Mineral Resource Strategy with comprehensive policy tools so as to effectively deal with the intensifying international competition in the field of rare mineral, better guarantee the sustainable use of rare minerals and safeguard national resource security. The scale economies can help to transform the strategic emerging industries from the infant stage or growth stage to maturity stage, and eventually make the strategic emerging industries become the main industries. Using the listed companies data in A-share 
market, Ren, B.Q. and Wang, L.L. (2014) [76] analyzed the scale economies of strategic emerging industries based on the whole industry, industrial classification, policy support and nature of property rights. The results showed that although the overall strategic emerging industries show significant scale economies, but based on the research of industrial classification, it revealed that the scale economies of some industries were not significant, even scale diseconomies. The policy support had the significant effect on scale economies of strategic emerging industries. The scale economies of state-owned enterprises in strategic emerging industries were not significant, but non-state-owned enterprises had significant scale economies.

\section{Research Prospect}

Based on the quantitative and qualitative analysis of the existing research literature, we believe that the researchers should:

\subsection{Focus on the Empirical Studies Based on the Development of the Practices}

According to the research literature on http://www.cnki.net/ from 2010 to 2014, we find that most articles belong to qualitative studies, theoretical studies, macroscopic studies, repetitive studies. Although we have made some progress in this field, we should focus on practical studies, empirical studies, quantitative studies, microscopic studies, and innovative studies in the future.

\subsection{Make Efforts to Construct a Whole Systematic Research Framework}

Recently, the studies on the strategic emerging industries have involved in many kinds of problems, but these studies are more spread out and lack of systematic and holistic. Based on this, we should actively explore the research problems about the high-level and sustainable development of strategic emerging industries, analyze the inherent relationship among them, and make efforts to construct a whole systematic research framework from the overall and long-term perspective.

\subsection{Pay More Attention to the Studies on Strategic Human Resources}

Core human resource is the key to the development of the strategic emerging industries. The scarcity of high-end scientific and technological human resources will become the important factor that restricts the future development of the strategic emerging industries. According to the research review, the studies on human resources of strategic emerging industries were still relatively in a small quantity. Therefore, we must pay more attention to the studies on how to develop and utilize strategic human resources scientifically.

\section{Funding}

This study was supported by grants from the National Social Science Foundation of China (to Jianmin Wang) (No.11AGL002).

\section{References}

[1] He, J. and Lv, T. (2012) Strategic Emerging Industry: From Policy Concept to Theoretical Issue. Finance \& Trade Economics, 5, 106-113.

[2] Wang, Y. and Liu, Z.B. (2013) Subsidies and Balanced Development: Growth of Strategic Emerging Industries and Adjustment of Traditional Industries. China Industrial Economics, 8, 57-69.

[3] Xiao, X.Z. and Jiang, X.J. (2013) Investment Direction of Government Innovation Fund in the Strategic Emerging Industries: Traditional Enterprises in Transition or Newborn Enterprises. China Industrial Economics, 1, 128-140.

[4] Han, C. (2014) Study on Policy Dependence Syndrome in Strategic Emerging Industries: Empirical Analysis from the Perspective of Local Government Subsidies. Economic Theory and Business Management, 11, 57-71.

[5] Wu, Q. and Liu, B. (2014) Research on the Influencing Mechanism of Modes of Distribution of Government R \& D Subsidy on the Innovation of Strategic Emerging Industries. Industrial Economics Research, 6, 41-49.

[6] Lu, G.Q., Wang, Z. and Zhang, C.Y. (2014) Research on the Performance of Subsidizing Innovation for Chinese Strategic Emerging Industry. Economic Research Journal, 7, 44-55.

[7] Wang, Q.M., Han, Q.X. and Yang, C. (2014) Government Subsidies and Corporate Behavior in Strategic Emerging 
Industries: A Perspective of Dynamic Game Based on Government Regulation. Journal of Finance and Economics, 7, 43-53.

[8] Xiao, X.Z. and Wang, Y.P. (2014) Government Subsidies and Enterprise Decision of Social Capital Investment: Evidence from Strategic Emerging Industries. China Industrial Economics, 9, 148-160.

[9] Gu, H.F. (2011) Study on Finance Supporting System and Policy to Strategic Emerging Industry Evolution: Based on Policy Finance Supporting Perspective. Science of Science and Management of S. \& T., 7, 98-103.

[10] Gu, H.F. (2011) Evolution of Industrial Forms and Financial Support of Strategic Emerging Industries in China. Securities Market Herald, 4, 57-61+66.

[11] Wu, J.X. and Li, X.Z. (2012) The Role \& Function of Local Government in the Development of Strategic Emerging Industries. Science of Science and Management of S. \& T., 8, 117-122.

[12] Zhai, H.Y. (2012) Research on Efficiency of the Financial Support of Listed Companies in Strategic Emerging Industries. Securities Market Herald, 11, 20-25.

[13] Chen, C. (2013) The Innovation, Problem and Countermeasures of Banking Industry Supporting the Development of Strategic Emerging Industries. Securities Market Herald, 6, 21-26.

[14] Zhou, C. and Zhou, H. (2011) Why Did Synthetic Ammonia First Realize Industrialization in Germany? —Also on the Policy Orientation of China's Cultivation for Strategic Emerging Industries. Science of Science and Management of S. \& T., 3, 78-86.

[15] Liu, C., Gu, Q. and Dong, R.Q. (2011) The Function of Industry Policy in the Development of Strategic Emerging Industries. Comparative Economic \& Social Systems, 1, 196-203.

[16] Li, K. and Chen, L.J. (2012) Research on Supporting Policy System for Strategic Emerging Industries Based on Double Helix Innovation Model. China Soft Science, 12, 179-186.

[17] Hu, H.F. and Hu, J.Y. (2011) The Comparative Analysis and Revelations on the Financing Mechanisms of Strategic Emerging Industries in U. S., Japan and Germany. Economic Theory and Business Management, 8, 62-74.

[18] Jia, G.L. and Yang, W. (2012) The Strategic Emerging Industries and American Economic Takeoff-Historical Experience and Enlightenment of American Iron and Steel Industry. Economic Theory and Business Management, 1, 97110.

[19] Xue, L., Lin, Z.L., Liang, Z., Chen, L., Zhou, Y. and Wang, X. (2013) The Development Trend of Strategic Emerging Industries around the World and Implications for China. China Soft Science, 5, 18-26.

[20] Wang, S.Y., Huo, G.Q., Sun, H. and Yang, Y. (2014) The Study on the Lifecycle and Evolution of Strategic Emerging Industries Based on the Case Study of Leading Industry of United Kingdom and American. Studies in Science of Science, 11, 1630-1638.

[21] He, Z.C., Zhang, X. and Zhou, Z.H. (2010) The Study of Strategic Emerging Industries' Selection System and Model. Science of Science and Management of S. \& T., 12, 62-67.

[22] Liu, H.C. (2011) Selective Principles of Chinese Strategic Emerging Industries and Research on Orientation of Cultivating Policies. Science of Science and Management of S. \& T., 3, 87-92.

[23] He, Z.C. and Wu, Y. (2011) Assessment Index System and Evaluating Model of Strategic Emerging Industries. Studies in Science of Science, 5, 678-683+721.

[24] Hu, Z.H., Li, C.Q. and Xiong, Y.Q. (2011) Research on Selection Model of Strategic Emerging Industries Based on Combination Weights: AHP-IE-PCA. Science of Science and Management of S. \& T., 7, 104-110.

[25] Guo, X.D. and Song, W.J. (2011) The Choice of Timing to Enter the Strategic Emerging Industries: Leading or Following. China Industrial Economics, 5, 119-128.

[26] Liu, T. and Wang, J.Y. (2012) A Study on Excessive Convergence in the Choice of Regional Strategic Emerging Industries. China Soft Science, 2, 115-127.

[27] Wang, C.W. (2013) Could Strategic Emerging Industries Be "Selected”? Science of Science and Management of S. \& T., 7, 131-140.

[28] Xiong, Y.Q. and Li, S.C. (2010) Analysis on the Coupling Process Industries and Function Mechanism of Strategic Emerging and Traditional Industries. Science of Science and Management of S. \& T., 11, 84-87+109.

[29] Zhang, G.S. (2012) Technological Revolution, Paradigms Shift and Development of Strategic Emerging Industries: A Study of Evolutionary Economics. Industrial Economics Research, 6, 26-32.

[30] Li, J. and Liu, X.F. (2012) Study on the Developing Path of Marine Strategic Emerging Industries in Fujian Province. Issues in Agricultural Economy, 2, 103-107.

[31] He, Z.C., Wu, Y., Zhang, M. and Wen, X.M. (2012) Study on the Convergence of Producer Service and Strategic Emerging Industries in China. Management World, 12, 177-178. 
[32] Zhang, S.R. (2012) Study on the Development of Strategic Emerging Industries and the Problem of Agricultural Industrialization: Taking the Developing Practices of Urban Agriculture in Wuhan for Example. Issues in Agricultural Economy, 2, 79-84.

[33] Lu, L.J. and Yu, B.B. (2012) Integrated Evolution of Traditional Industries and Strategic Emerging Industries and Government Behavior: Theory and Evidence. China Soft Science, 5, 28-39.

[34] Chen, Y.T., Cheng, P. and Liang, Z. (2012) Influential Factors of Strategic Emerging Industries Evolution: an Analysis Framework of Two Stage-Four Dimensions-Empirical Studies Based on Wind Turbine Industry in China. Studies in Science of Science, 8, 1187-1197.

[35] He, Z.C., Wu, Y., Jiang, J.L. and Chen, Y.M. (2013) Analyzing, Evaluating and Measuring the Interaction and Integration between Producer Services and Strategic Emerging Industries. China Soft Science, 5, 129-143.

[36] Wang, K.K. (2013) The Choice of “Multi-Step” Developing Path of Strategic Emerging Industries in China: An Analysis Based on Karl Marx’s Theory of Resources Allocation. Economist, 6, 21-29.

[37] Xiong, Y.Q. and Yu, Y. (2013) Research on the Docking Path and Model between Traditional Enterprise and Strategic Emerging Industry. Science of Science and Management of S. \& T., 9, 107-115.

[38] Jiang, H. (2014) Evolution of Strategic Emerging Industry System Based on Self-Organization Theory: Uncertainty and Transition. Science of Science and Management of S. \& T., 1, 126-131.

[39] Liu, Z.Y. (2010) Study on the Formation Mechanism and Competitive Strategy of the Dominant Design of Strategic Emerging Industries. Comparative Economic \& Social Systems, 5, 165-172.

[40] Xiao, S.G. (2011) Labor and Capital Distribution in Organizations of Strategic Emerging Industries. China Industrial Economics, 2, 100-109.

[41] Zhou, H.Y., He, Z.C. and Zhang, X. (2011) Strategic Emerging Industries and Optimization and Upgrading of Industrial Structure in China. Economic Geography, 12, 2060-2064.

[42] Qiao, X.N. and Li, H.S. (2011) Study on the Growth Mechanism of Strategic Emerging Industries in China Based on the Experience of Sewage Treatment Industry. Comparative Economic \& Social Systems, 2, 69-77.

[43] Liu, K. and Han, L.M. (2012) Study on the Formation Mechanism of Marine Strategic Emerging Industries. Issues in Agricultural Economy, 12, 90-96.

[44] Xiao, X.Z., He, W.T. and Guo, X.D. (2014) Competence Accumulation, Expansion Behaviors and the Duration of Enterprises' Survival: Study Based on the Enterprises' Survival of Chinese Strategic Emerging Industries. Management World, 2, 77-89.

[45] Liu, X.L., Gao, W., Lv, P. and Cheng, P. (2012) The Implication of Development of Photovoltaic Industry for Strategic Emerging Industry in China. Science of Science and Management of S. \& T., 1, 116-125.

[46] Liu, Z.B. (2012) Seeking for Policies to Promote Chinese Strategic Emerging Industries. Industrial Economics Research, 3, 9-17.

[47] Yang, Y.W., Zheng, J.H. and Huang, Y.C. (2012) The Coordinated Development between Productive Service Industry and Strategic Emerging Industry: Based on the General Equilibrium Analysis of the Productive Service Industry. Modern Economic Science, 6, 15-25+122.

[48] Huang, Y.C., Zheng, J.H., Tan, H.B. and Yang, Y.W. (2012) The Catch-Up Path and Time Choice of the Development Strategic Emerging Industries in Backward Area: Taking Flat Panel Display Technology as Example. Studies in Science of Science, 7, 1031-1038.

[49] Lin, X.J. (2012) Study on the Development and Formation Pattern of Strategic Emerging Industries. China Soft Science, 2, 26-34.

[50] Shen, J.X. (2012) Development Strategy Research from the Perspective of Innovation Modes for Industry-UniversityInstitute Cooperation on the Emerging Industries of Strategic Importance. Science of Science and Management of S. \& T., 2, 37-43.

[51] Li, X.H. and Liu, F. (2013) Industrial Ecosystem and the Development of Strategic Emerging Industries. China Industrial Economics, 3, 20-32.

[52] Ren, B.Q. and Wang, L.L. (2014) Are Strategic Emerging Industries Becoming High-End? The Journal of Quantitative \& Technical Economics, 3, 38-55.

[53] Yu, D.K., Tu, G.P. and Chen, H. (2012) Path and Pattern of Cooperation Development of Strategic Emerging Industry Cluster. Science of Science and Management of S. \& T., 4, 114-120.

[54] Zhao, Y.L. and Shi, F.F. (2012) An Empirical Analysis on Organizational Effect of the Strategic Emerging Industries cluster in China: From Investigation on Wuhan Biolake. Science of Science and Management of S. \& T., 10, 89-98.

[55] Wang, Q.W. and Wang, X.Y. (2013) A Study on the Ecosystem of Custer Brands in Strategic Emerging Industries. 
Science Research Management, 10, 153-160.

[56] Li, S.L. and Chen, Z.W. (2014) The Impact of Strategic Emerging Industrial Agglomeration on FDI Technology Spillovers: An Empirical Study Based on Agglomeration Degree of Different Dimensions in Transition Period. Securities Market Herald, 11, 29-36.

[57] Zhang, Z.H., Huang, H.X., Xie, Z.Q. and Sun, L.J. (2014) The Research on Formation Mechanism of Strategic Emerging Industries Colony: Taking Wuhan Optics Valley of China as Example. Studies in Science of Science, 1, $24-28$.

[58] Luan, C.J. (2012) Research on the Measuring Indicators of Generic Technology of Emerging Industries of Strategic Importance. Science of Science and Management of S. \& T., 2, 11-16.

[59] Huang, L.C, Wang, K.K., Wu, F.F., Miao, H. and Lou, Y. (2012) The Evaluation Indicators and Standards for Technological Characteristic of Strategic Emerging Industries. Science of Science and Management of S. \& T., 7, $103-108$.

[60] Yu, J. and Chen, K.H. (2012) Current Situation and Challenge of Technological Innovations in Chinese Strategic Emerging Industries: A Patent-Bibliometric Perspective. Studies in Science of Science, 5, 682-695.

[61] Lv, Y.W. and Sun, H. (2013) Study on Technical Efficiency of Chinese Strategic Emerging Industries and Its Influencing Factors: Based on 18 Industries Data. Science of Science and Management of S. \& T., 11, 137-146.

[62] Wu, S.B. (2013) Study on the Strategic Emerging Industries Innovation Ecosystem’s Knowledge Inputs Incentive of Collaborative Innovation. Science of Science and Management of S. \& T., 9, 71-76.

[63] Wu, L. and Zhang, Y.G. (2013) The Analysis on Innovation Efficiency of Regional Strategic Emerging Industry Based on SFA: A Case of Beijing Pharmaceutical and IT Industry. Science of Science and Management of S. \& T., 10, 95102.

[64] Sun, Y.T. and Li, M.M. (2013) Local Factors on the Fostering Enterprises’ Technological Innovation Capability: An Empirical Study Based on Enlisted Companies in China’s Strategic Emerging Industries. Science of Science and Management of S. \& T., 8, 129-137.

[65] Xing, H.P. and Wei, P. (2013) A Study on the Behavior Pattern of Technological Innovation of China's Strategic Emerging Industries: Based on the Questionnaire from Seven Provinces and Cities Nationwide. Economist, 4, 56 - 65.

[66] Yue, Z.G. (2014) Research on Collaborative Development of Technical Chain and Industrial Chain of Strategic Emerging Industries. Science of Science and Management of S. \& T., 2, 154-161.

[67] Li, Y.H. (2014) Corporate Governance and Enterprises’ Heterogeneous R\&D Innovation: An Empirical Study Based on GEM Listed Companies in Strategic Emerging Industries. Securities Market Herald, 12, 26-31.

[68] Xiong, Y.Q., Bai, Y. and Chen, X.H. (2014) Enterprise Partner Evaluation of Generic Technology Development in Strategic Emerging Industries: Construction and Application of Double-Dimension and Two-Phase Model. Science Research Management, 8, 68-74.

[69] Wu, J.L. and Wang, H.Q. (2014) Research on Radical Technology Innovation Paths of Strategic Emerging Industries: from the Perspective of Modularization. Studies in Science of Science, 4, 508-518.

[70] Tan, R.J. (2012) The Dimension Structure and Measurement of Strategic New Industry Competitiveness: Based on Empirical Data of Guangdong Province in the Context of the Low-Carbon Economy. Studies in Science of Science, $\mathbf{5}$, 673-681.

[71] Ling, J.H. and Hu, W.R. (2012) Firm Size, Capital Structure and Operating Performance: Comparative Study on Traditional Industries and Strategic Emerging Industries. Finance \& Trade Economics, 12, 71-77.

[72] Zhang, R. (2014) Research on Performance Evaluation of Strategic Emerging Industries. Accounting Research, 8, 41-44+96

[73] Cheng, G.S. and Zhu, H.J. (2014) Market Performance of Strategic Emerging Industries for Private Enterprises: Empirical Analysis Based on Panel Data of 21 Industries. Science of Science and Management of S. \& T., 1, 109-116.

[74] Wang, J. and Zhang, Z. (2014) The Development Efficiency Measurement and Financial Support of Strategic Emerging Industries. Journal of Zhongnan University of Economics and Law, 1, 76-81.

[75] Li, P.F., Yang, D.H., Qu, S.N. and Zhang, Y.F. (2014) A Strategic Assessment of Rare Minerals Based on the Perspective of Strategic Emerging Industries Development. China Industrial Economics, 7, 44-57.

[76] Ren, B.Q. and Wang, L.L. (2014) Do Scale Economies of Strategic Emerging Industries Exist?_-The Analysis Based on Industry Classification, Policy and Property Right. Industrial Economics Research, 3, 42-50+90. 